\title{
Assessment of Selected Water-Quality Data Collected in the Lower Red River (Main Stem) Basin, Texas, 1997-98
}

The Texas part of the Red River Basin has been divided into five reaches or subbasins (fig. 1) to facilitate improved planning, monitoring, geographical analysis, and dissemination of information. The U.S. Geological Survey (USGS), in cooperation with the Red River Authority of Texas, is studying the five subbasins, each for a period of about 1 year. Baldys and Phillips (1998) discuss various components and the associated scope of study of each of the five reaches. Data from the first reach studied - reach 2, the Wichita River Basin-were presented in a fact sheet by Baldys and Phillips (2000). This fact sheet presents an assessment of data collected at 11 sites during 1997-98 for reach 1-the lower Red River (main stem) Basin from the confluence of Cache Creek downstream to the Texas-Arkansas State Line (fig. 1).

\section{Lower Red River (Main Stem) Basin}

The drainage basin of the lower Red River (main stem) reach in Texas covers 3,600 square miles (fig. 1). Four major cities are in this narrow strip of land: Denison (population 22,773), Sherman (population 35,082), Paris (population 25,898), and Texarkana (population 34,782 in Texas, and 26,448 in Arkansas) (Dallas Morning News, 2001).

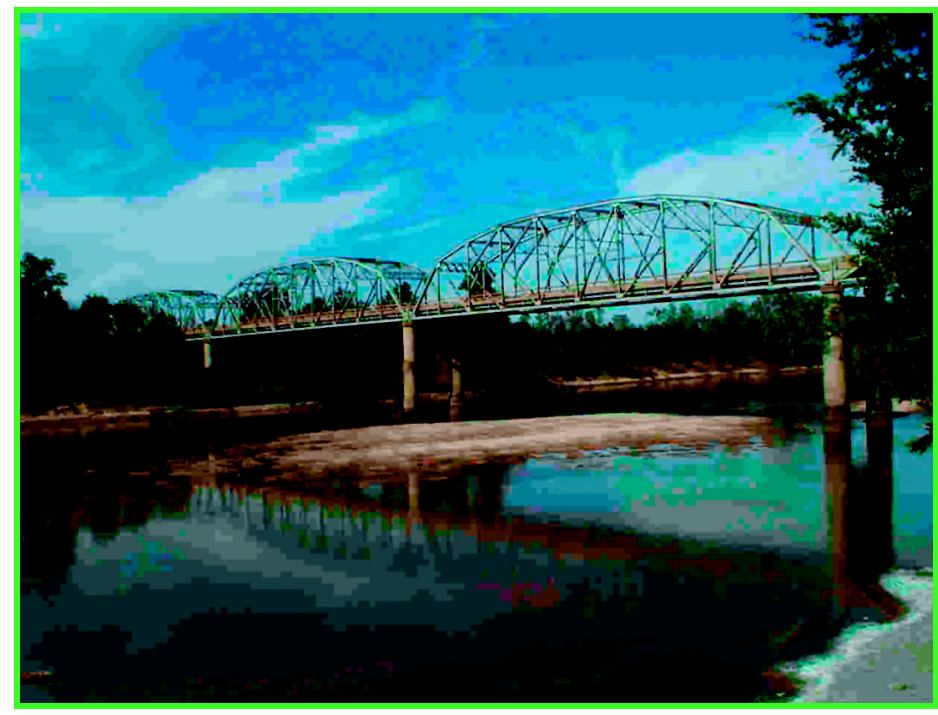

A. Red River near Bonham, Texas (photograph courtesy of William S. Burns, Red River Authority of Texas).
The primary hydrologic influences on the Red River in this reach are Lake Nocona, Lake Texoma, and Pat Mayse Lake in Texas and Hugo Lake in Oklahoma (not shown on map), about 30 miles north of Paris, Tex. The daily mean flow at USGS streamflow-gaging station 07315500 Red River near Terral, Okla. (upstream boundary of lower Red River main stem), was 2,571 cubic feet per second $\left(\mathrm{ft}^{3} / \mathrm{s}\right)$ for water years 1938-98; daily mean flow at USGS station 07337000 Red River at Index, Ark. (downstream boundary of lower Red River main stem), was $13,310 \mathrm{ft}^{3} / \mathrm{s}$ for water years $1944-98$ (table 1) (Gandara and others, 1998, 1999). Annual mean flows at both stations for water years 1997 and 1998 were higher at Terral (60 and 20 percent) and at Index (65 and 25 percent) than the historical averages for both sites. Major tributaries to the main stem of the lower Red River are the Washita River, which flows into the north side of Lake Texoma from Oklahoma (daily mean discharge 2,692 $\mathrm{ft}^{3} / \mathrm{s}$ in 1998 and 3,602 $\mathrm{ft}^{3} / \mathrm{s}$ in 1997 at station 07331000

Washita River near Dickson, Okla. [Blazs and others, 1998, 1999]), and Big Mineral Creek (ungaged), Choctaw Creek (ungaged), and Bois D'Arc Creek (ungaged) from Texas. Discharge for both the 1997 and 1998 water years measured at station 07331000 was higher than the 1962-98 average annual mean of $1,904 \mathrm{ft}^{3} / \mathrm{s}$ (Blazs and others, 1999).

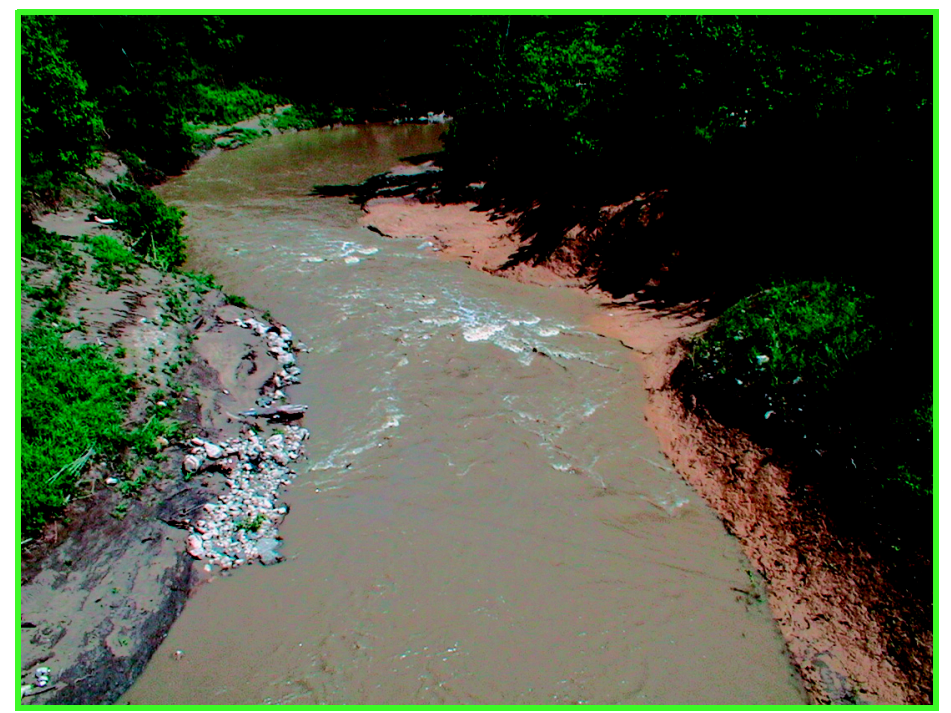

B. Choctaw Creek at U.S. Highway 69 near Denison, Texas (photograph courtesy of William S. Burns, Red River Authority of Texas). 


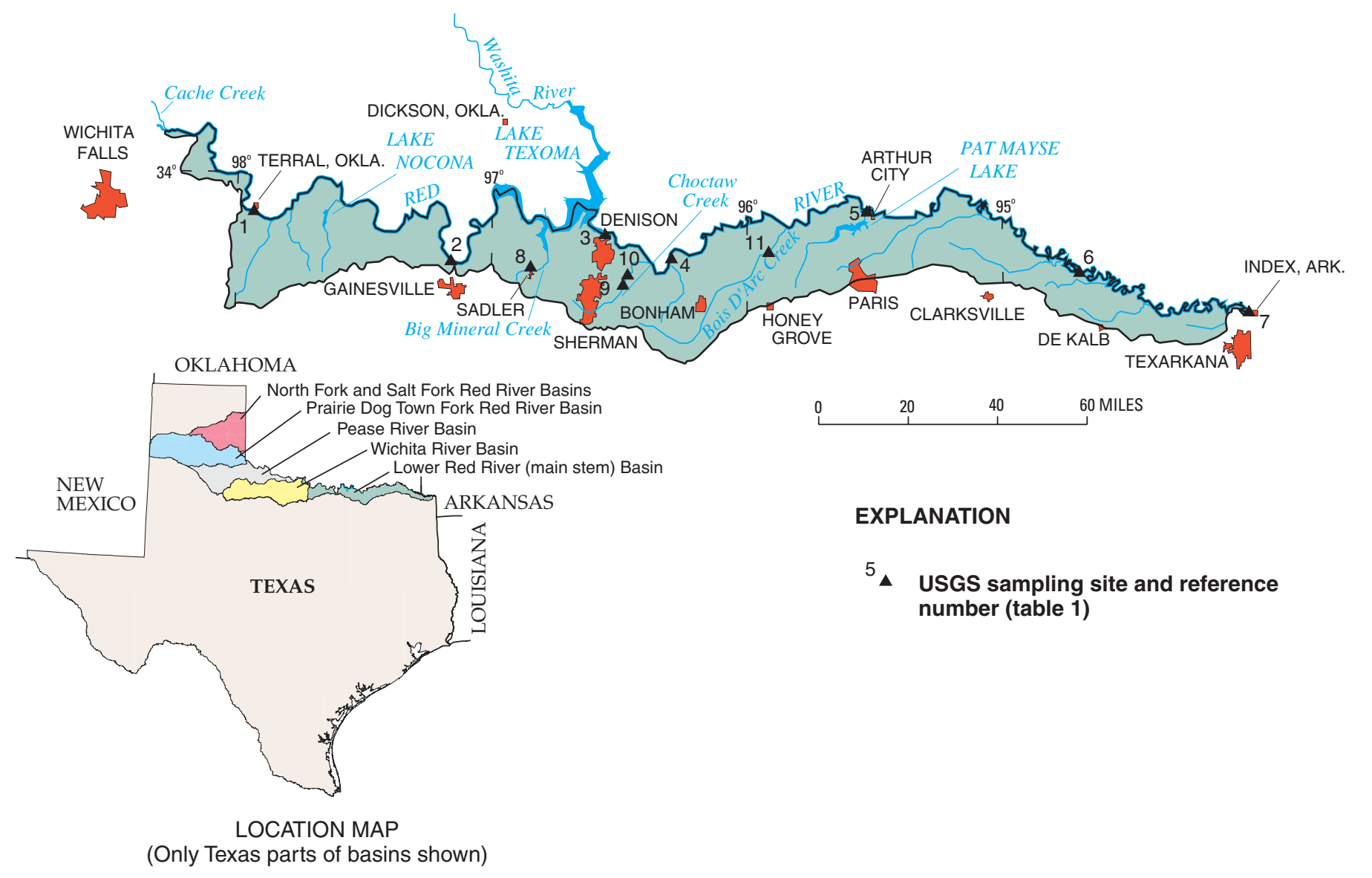

Figure 1. Sampling sites in the lower Red River (main stem) Basin, Texas 1997-98.

The lower Red River in the main stem reach can be quite wide with main channels greater than 1,000 feet (ft) wide (Red River near Bonham, Tex., photograph A) and flood plains wider than 5,000 ft. Channels primarily are composed of highly erodible, mobile sand that often changes the location of the low-flow channel after a flood. The tributaries to the main stem are characterized by more stable, smaller channels with much smaller floodplains that generally are covered with brush and trees (Choctaw Creek at U.S. Highway 69 near Denison, Tex., photograph B).

Water-quality data were collected by the Red River Authority of Texas and the USGS at seven sites on the main

Table 1. Monitoring program in the lower Red River (main stem) Basin, Texas, 1997-98

[TCEQ, Texas Commission on Environmental Quality; USGS, U.S. Geological Survey; C, continuous recording; --, not applicable; I, intermittent recording; Hwy., Highway; FM, Farm to Market Road]

\begin{tabular}{|c|c|c|c|c|c|c|}
\hline \multirow{2}{*}{$\begin{array}{c}\text { Sampling } \\
\text { site no. } \\
\text { (fig. 1) }\end{array}$} & \multirow[b]{2}{*}{ Site name } & \multicolumn{2}{|c|}{ Station ID } & \multirow[b]{2}{*}{ Latitude } & \multirow[b]{2}{*}{ Longitude } & \multirow{2}{*}{$\begin{array}{l}\text { Discharge } \\
\text { monitored }\end{array}$} \\
\hline & & TCEQ & USGS & & & \\
\hline 1 & Red River near Terral, Okla. & 10133 & 07315500 & $33^{\circ} 52^{\prime} 43^{\prime \prime}$ & $97^{\circ} 56^{\prime} 03^{\prime \prime}$ & $\mathrm{C}$ \\
\hline 2 & Red River near Gainesville, Tex. & 10132 & 07316000 & $33^{\circ} 43^{\prime} 40^{\prime \prime}$ & $97^{\circ} 09^{\prime} 35^{\prime}$ & $\mathrm{C}$ \\
\hline 3 & Red River at Denison Dam near Denison, Tex. & 13684 & 07331600 & $33^{\circ} 49^{\prime} 08^{\prime \prime}$ & $96^{\circ} 33^{\prime} 47^{\prime \prime}$ & $\mathrm{C}$ \\
\hline 4 & Red River near Bonham, Tex. & 10127 & -- & $33^{\circ} 45^{\prime} 25^{\prime \prime}$ & $96^{\circ} 12^{\prime} 07^{\prime \prime}$ & I \\
\hline 5 & Red River at U.S. Hwy. 271 at Arthur City, Tex. & 10126 & 07335500 & $33^{\circ} 52^{\prime} 30^{\prime \prime}$ & $95^{\circ} 30^{\prime} 06^{\prime \prime}$ & $\mathrm{C}$ \\
\hline 6 & Red River near De Kalb, Tex. & 10125 & 07336820 & $33^{\circ} 40^{\prime} 59^{\prime \prime}$ & $94^{\circ} 41^{\prime} 39^{\prime \prime}$ & $\mathrm{C}$ \\
\hline 7 & Red River at Index, Ark. & 10123 & 07337000 & $33^{\circ} 33^{\prime} 07^{\prime \prime}$ & $94^{\circ} 02^{\prime} 28^{\prime \prime}$ & $\mathrm{C}$ \\
\hline 8 & Big Mineral Creek at FM 901 near Sadler, Tex. & 15320 & -- & $33^{\circ} 42^{\prime} 07^{\prime \prime}$ & $96^{\circ} 50^{\prime} 53^{\prime \prime}$ & I \\
\hline 9 & Choctaw Creek at U.S. Hwy. 69 near Denison, Tex. & 16123 & -- & $33^{\circ} 41^{\prime} 10^{\prime \prime}$ & $96^{\circ} 28^{\prime} 19^{\prime \prime}$ & I \\
\hline 10 & Choctaw Creek at FM 1753 near Denison, Tex. & 16130 & -- & $33^{\circ} 43^{\prime} 08^{\prime \prime}$ & $96^{\circ} 27^{\prime} 14^{\prime \prime}$ & I \\
\hline 11 & Bois D'Arc Creek at FM 100 near Honey Grove, Tex. & 15318 & -- & $33^{\circ} 45^{\prime} 32^{\prime \prime}$ & $95^{\circ} 54^{\prime} 58^{\prime \prime}$ & I \\
\hline
\end{tabular}




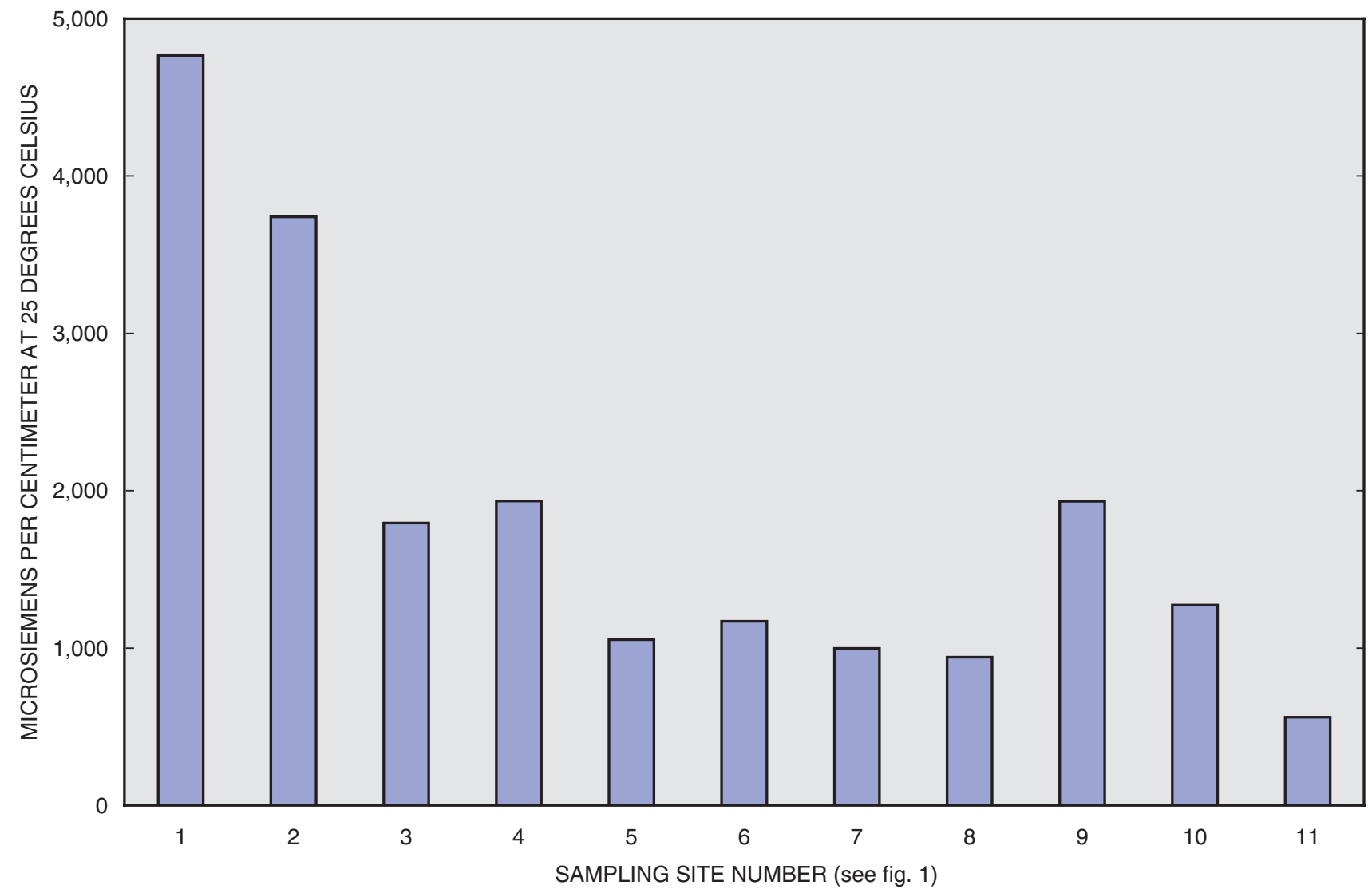

Figure 2. Median specific conductance at lower Red River (main stem) Basin sampling sites decreases in concentration through the basin, 1997-98.

stem of the Red River and four sites on tributaries to the main stem of the Red River (table 1). The major waterquality issues in this reach of the lower Red River Basin identified by the Texas Commission on Environmental Quality (TCEQ) are salinity, bacteria, and dissolved oxygen concentrations (Texas Natural Resource Conservation Com- mission, 1997). The salinity of a water body refers to its concentration of dissolved solids. Waters with low salinity (freshwater-less than 1,000 milligrams per liter [mg/L] dissolved solids) is suitable for agriculture and potable water supplies, whereas waters with higher salinity make good habitats for certain species of fish. Bacteria have been

Table 2. Specific conductance in the lower Red River (main stem) Basin, Texas, 1997-98

$[\mu \mathrm{S} / \mathrm{cm}$, microsiemens per centimeter at 25 degrees Celsius; USGS, U.S. Geological Survey; RRA, Red River Authority of Texas; --, not applicable; Hwy., Highway; FM, Farm to Market Road]

\begin{tabular}{|c|c|c|c|c|c|c|c|c|}
\hline \multirow{2}{*}{$\begin{array}{l}\text { Sam- } \\
\text { pling } \\
\text { site no. } \\
\text { (fig. 1) }\end{array}$} & \multirow{2}{*}{ Site name } & \multicolumn{5}{|c|}{$\begin{array}{l}\text { Specific conductance } \\
(\mu \mathrm{S} / \mathrm{cm})\end{array}$} & \multirow{2}{*}{$\begin{array}{c}\text { No. of } \\
\text { discrete } \\
\text { samples }\end{array}$} & \multirow{2}{*}{$\begin{array}{c}\text { Data } \\
\text { source }\end{array}$} \\
\hline & & $\begin{array}{l}\text { Mini- } \\
\text { mum }\end{array}$ & $\begin{array}{l}\text { Maxi- } \\
\text { mum }\end{array}$ & Median & $\begin{array}{l}\text { Aver- } \\
\text { age }\end{array}$ & $\begin{array}{c}\text { Continuous } \\
\text { monitor average }\end{array}$ & & \\
\hline 1 & Red River near Terral, Okla. & ${ }^{1} 653$ & ${ }^{1} 20,600$ & ${ }^{1} 4,765$ & ${ }^{1} 4,902$ & 3,794 & 24 & USGS, RRA \\
\hline 2 & Red River near Gainesville, Tex. & ${ }^{1} 1,090$ & ${ }^{1} 6,030$ & $1_{3,740}$ & $1_{3,847}$ & 3,527 & 35 & USGS, RRA \\
\hline 3 & Red River at Denison Dam near Denison, Tex. & ${ }^{1} 1,400$ & ${ }^{1} 1,990$ & ${ }^{1} 1,795$ & ${ }^{1} 1,786$ & 1,478 & 24 & USGS \\
\hline 4 & Red River near Bonham, Tex. & 1,402 & 2,010 & 1,934 & 1,876 & -- & 9 & RRA \\
\hline 5 & Red River at U.S. Hwy. 271 at Arthur City, Tex. & 173 & 1,496 & 1,053 & 963 & -- & 15 & USGS \\
\hline 6 & Red River near De Kalb, Tex. & 617 & 1,570 & 1,170 & 1,149 & -- & 16 & USGS, RRA \\
\hline 7 & Red River at Index, Ark. & 276 & 1,443 & 998 & 945 & -- & 24 & USGS, RRA \\
\hline 8 & Big Mineral Creek at FM 901 near Sadler, Tex. & 443 & 1,337 & 942 & 908 & -- & 12 & RRA \\
\hline 9 & Choctaw Creek at U.S. Hwy. 69 near Denison, Tex. & 522 & 2,509 & 1,933 & 1,630 & -- & 8 & RRA \\
\hline 10 & Choctaw Creek at FM 1753 near Denison, Tex. & 658 & 1,763 & 1,272 & 1,242 & -- & 4 & RRA \\
\hline 11 & Bois D'Arc Creek at FM 100 near Honey Grove, Tex. & 210 & 1,017 & 560 & 596 & -- & 12 & RRA \\
\hline
\end{tabular}

${ }^{1}$ Statistics pertain to discrete samples only. 


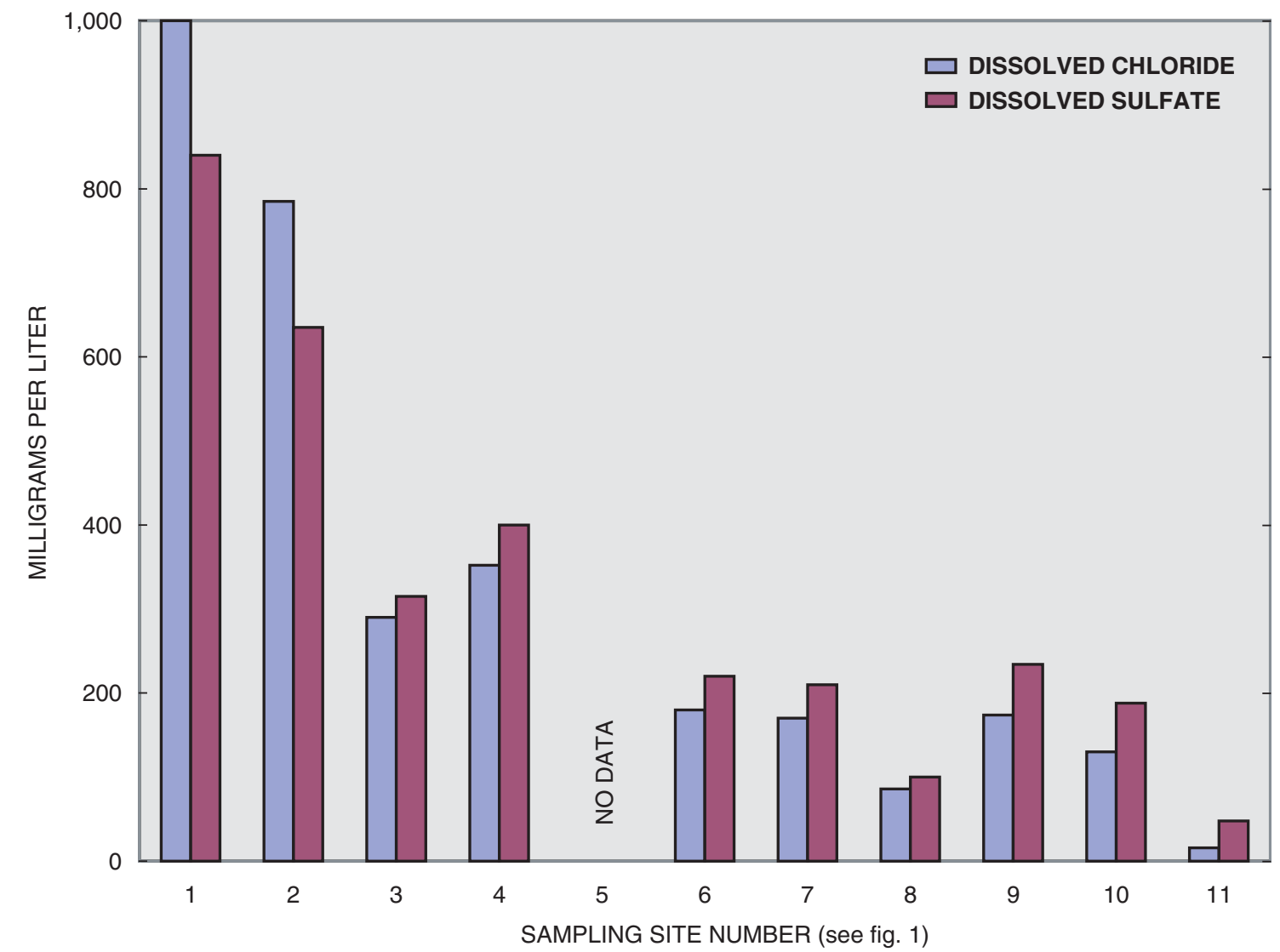

Figure 3. Median dissolved chloride and sulfate at lower Red River (main stem) Basin sampling sites decrease in concentration through the basin, 1997-98.

included on the Clean Water Act 303(d) list for Texas ${ }^{1}$ as an indication of an impaired or threatened water body. Dissolved oxygen concentrations need to average at least $5.0 \mathrm{mg} / \mathrm{L}$, with an absolute minimum of $3.0 \mathrm{mg} / \mathrm{L}$, to sustain healthy fish populations (Texas Natural Resource Conservation Commission, 1997).

\section{Salinity}

Salinity is an issue in the main stem reach of the lower Red River, especially in Lake Texoma, because of its effects on striped bass fishing, which is a major industry in the area. Specific conductance (table 2) is an indicator of the salinity in a water body and correlates closely with dissolved chloride and dissolved sulfate concentrations. Relations between specific conductance and dissolved sulfate or dissolved chloride concentrations, or both, have been developed at several sites in the Red River Basin and used to compute loads for chloride and sulfate (Gandara and others, 1999).

\footnotetext{
${ }^{1}$ The Clean Water Act 303(d) list for Texas comprises surface-water bodies identified by the TCEQ as impaired (do not meet applicable waterquality standards) or threatened (are not expected to meet applicable standards in the near future). Section 303(d) of the Federal Clean Water Act (together with related regulations) requires each State to assess the quality of its surface waters and to develop water-quality improvement strategies for impaired and threatened waters.
}

Specific conductance was measured hourly with an electronic probe at two sites, 07316000 Red River near Gainesville, Tex. (upstream from Lake Texoma), and 07331600 Red River at Denison Dam near Denison, Tex. (downstream from Lake Texoma), and by discrete daily samples at site 07315500 Red River near Terral, upstream from the Gainesville site. The continuous monitor averages for these three sites are lower than the medians for discrete samples collected periodically at the sites during the study period. Specific conductance in the lower Red River generally decreases in a downstream direction (fig. 2), except for the two Choctaw Creek sites (table 2). Median specific conductance decreased substantially from the Terral site (4,765 microsiemens per centimeter at 25 degrees Celsius $[\mu \mathrm{S} / \mathrm{cm}])$, to the Gainesville site $(3,740 \mu \mathrm{S} / \mathrm{cm}$ ) (both above Lake Texoma), to the outflow site for Lake Texoma at Denison Dam $(1,795 \mu \mathrm{S} / \mathrm{cm})$. Moving downstream, median specific conductance for discrete samples increased slightly at the Bonham site $(1,934 \mu \mathrm{S} / \mathrm{cm})$, decreased to 1,053 $\mu \mathrm{S} / \mathrm{cm}$ at the U.S. Highway 271 site at Arthur City, and then increased slightly again to $1,170 \mu \mathrm{S} / \mathrm{cm}$ at the De Kalb site. Median specific conductance for discrete samples in the lower Red River main stem as it leaves the study reach at Index, Ark., is the lowest of all main stem sites, $998 \mu \mathrm{S} / \mathrm{cm}$. 
Table 3. Dissolved chloride and dissolved sulfate concentrations in the lower Red River (main stem) Basin, Texas, 1997-98

[mg/L, milligrams per liter; USGS, U.S. Geological Survey; RRA, Red River Authority of Texas; --, not sampled; Hwy., Highway; FM, Farm to Market Road]

\begin{tabular}{|c|c|c|c|c|c|c|c|c|c|c|c|c|}
\hline \multirow{2}{*}{$\begin{array}{l}\text { Sam- } \\
\text { pling } \\
\text { site no. } \\
\text { (fig. 1) }\end{array}$} & \multirow{2}{*}{ Site name } & \multicolumn{4}{|c|}{$\begin{array}{c}\text { Dissolved chloride } \\
(\mathrm{mg} / \mathrm{L})\end{array}$} & \multirow{2}{*}{$\begin{array}{l}\text { No. of } \\
\text { sam- } \\
\text { ples }\end{array}$} & \multicolumn{4}{|c|}{$\begin{array}{c}\text { Dissolved sulfate } \\
(\mathrm{mg} / \mathrm{L})\end{array}$} & \multirow{2}{*}{$\begin{array}{l}\text { No. of } \\
\text { sam- } \\
\text { ples }\end{array}$} & \multirow{2}{*}{$\begin{array}{l}\text { Data } \\
\text { source }\end{array}$} \\
\hline & & $\begin{array}{l}\text { Mini- } \\
\text { mum }\end{array}$ & $\begin{array}{l}\text { Maxi- } \\
\text { mum }\end{array}$ & Median & $\begin{array}{l}\text { Ave- } \\
\text { rage }\end{array}$ & & $\begin{array}{l}\text { Mini- } \\
\text { mum }\end{array}$ & $\begin{array}{l}\text { Maxi- } \\
\text { mum }\end{array}$ & Median & $\begin{array}{l}\text { Aver- } \\
\text { age }\end{array}$ & & \\
\hline 1 & Red River near Terral, Okla. & 560 & 1,400 & 1,000 & 950 & 6 & 590 & 950 & 840 & 793 & 6 & USGS \\
\hline 2 & Red River near Gainesville, Tex. & 190 & 1,400 & 785 & 818 & 24 & 140 & 1,000 & 635 & 637 & 24 & USGS \\
\hline 3 & Red River at Denison Dam near Denison, Tex. & 210 & 360 & 290 & 290 & 24 & 240 & 410 & 315 & 321 & 24 & USGS \\
\hline 4 & Red River near Bonham, Tex. & 300 & 370 & 352 & 341 & 3 & 280 & 434 & 400 & 371 & 3 & RRA \\
\hline 5 & Red River at U.S. Hwy. 271 at Arthur City, Tex. & -- & -- & -- & -- & -- & -- & -- & -- & -- & -- & -- \\
\hline 6 & Red River near De Kalb, Tex. & 96 & 230 & 180 & 172 & 11 & 120 & 260 & 220 & 202 & 11 & USGS \\
\hline 7 & Red River at Index, Ark. & 150 & 190 & 170 & 170 & 5 & 180 & 220 & 210 & 204 & 5 & USGS \\
\hline 8 & Big Mineral Creek at FM 901 near Sadler, Tex. & 76 & 144 & 86 & 98 & 4 & 90 & 135 & 100 & 114 & 4 & RRA \\
\hline 9 & Choctaw Creek at U.S. Hwy. 69 near Denison, Tex. & 64 & 284 & 174 & 174 & 2 & 150 & 319 & 234 & 234 & 2 & RRA \\
\hline 10 & Choctaw Creek at FM 1753 near Denison, Tex. & 28 & 231 & 130 & 130 & 2 & 105 & 270 & 188 & 188 & 2 & RRA \\
\hline 11 & Bois D'Arc Creek at FM 100 near Honey Grove, Tex. & 11 & 21 & 16 & 16 & 2 & 44 & 52 & 48 & 48 & 2 & RRA \\
\hline
\end{tabular}

Table 4. Bacteria densities in the lower Red River (main stem) Basin, Texas, 1997-98

[cols./100 mL, colonies per 100 milliliters; <, less than; USGS, U.S. Geological Survey; RRA, Red River Authority of Texas; --, not sampled; Hwy., Highway; FM, Farm to Market Road]

\begin{tabular}{|c|c|c|c|c|c|c|c|c|c|c|}
\hline \multirow{2}{*}{$\begin{array}{c}\text { Sam- } \\
\text { pling } \\
\text { site no. } \\
\text { (fig. 1) }\end{array}$} & \multirow{2}{*}{ Site name } & \multicolumn{3}{|c|}{$\begin{array}{l}\text { Fecal coliform } \\
\text { (cols./100 mL) }\end{array}$} & \multirow{2}{*}{$\begin{array}{l}\text { No. } \\
\text { of } \\
\text { sam- } \\
\text { ples }\end{array}$} & \multicolumn{3}{|c|}{$\begin{array}{l}\text { Escherichia coliform } \\
\text { (cols./100 mL) }\end{array}$} & \multirow{2}{*}{$\begin{array}{c}\text { No. } \\
\text { of } \\
\text { sam- } \\
\text { ples }\end{array}$} & \multirow{2}{*}{$\begin{array}{l}\text { Data } \\
\text { source }\end{array}$} \\
\hline & & $\begin{array}{l}\text { Mini- } \\
\text { mum }\end{array}$ & $\begin{array}{l}\text { Maxi- } \\
\text { mum }\end{array}$ & $\begin{array}{c}\text { Geometric } \\
\text { mean }\end{array}$ & & $\begin{array}{l}\text { Mini- } \\
\text { mum }\end{array}$ & $\begin{array}{l}\text { Maxi- } \\
\text { mum }\end{array}$ & $\begin{array}{c}\text { Geometric } \\
\text { mean }\end{array}$ & & \\
\hline 1 & Red River near Terral, Okla. & $<1$ & 5,800 & 74 & 20 & 4 & 4,300 & 252 & 5 & USGS, RRA \\
\hline 2 & Red River near Gainesville, Tex. & 2 & 3,000 & 96 & 11 & -- & -- & -- & -- & RRA \\
\hline 3 & Red River at Denison Dam near Denison, Tex. & -- & -- & -- & -- & -- & -- & -- & -- & -- \\
\hline 4 & Red River near Bonham, Tex. & 16 & 300 & 77 & 7 & 20 & 300 & 60 & 7 & RRA \\
\hline 5 & Red River at U.S. Hwy. 271 at Arthur City, Tex. & 5 & 500 & 55 & 15 & -- & -- & -- & -- & RRA \\
\hline 6 & Red River near De Kalb, Tex. & 42 & 2,100 & 155 & 4 & -- & -- & -- & -- & USGS \\
\hline 7 & Red River at Index, Ark. & 6 & 2,000 & 43 & 22 & $<1$ & 13 & 5.1 & 5 & USGS, RRA \\
\hline 8 & Big Mineral Creek at FM 901 near Sadler, Tex. & $<1$ & 956 & 159 & 11 & 43 & 8,325 & 270 & 11 & RRA \\
\hline 9 & Choctaw Creek at U.S. Hwy. 69 near Denison, Tex. & $<1$ & 753 & 38 & 8 & 1 & $<1,000$ & 204 & 7 & RRA \\
\hline 10 & Choctaw Creek at FM 1753 near Denison, Tex. & 8 & 453 & 52 & 3 & 21 & 622 & 105 & 4 & RRA \\
\hline 11 & Bois D'Arc Creek at FM 100 near Honey Grove, Tex. & 3 & 400 & 107 & 11 & $<1$ & 720 & 95 & 11 & RRA \\
\hline
\end{tabular}

The primary constituents responsible for salinity are dissolved chloride and dissolved sulfate ions. The primary source of elevated dissolved chloride and sulfate concentrations are salt springs in the western (headwaters) part of the basin, which can have salinities that exceed those of seawater (Keller and others, 1988). Average dissolved chloride concentrations of as much as $10,600 \mathrm{mg} / \mathrm{L}$ and dissolved sulfate concentrations of as much as $2,800 \mathrm{mg} / \mathrm{L}$ were measured in samples from the South Wichita River, a major upstream tributary to the Red River, during 1996-97

(Baldys and Phillips, 2000). The median dissolved chloride concentration for discrete samples collected at the Red River near Terral site is $1,000 \mathrm{mg} / \mathrm{L}$ (table 3). Dissolved chloride concentrations generally decreased in a downstream direction (fig. 3) to a median concentration of 170 $\mathrm{mg} / \mathrm{L}$ at Red River near Index, Ark. Median concentrations in the tributaries were highest at both Choctaw Creek sites $(174 \mathrm{mg} / \mathrm{L}$ at the U.S. Highway 69 site and $130 \mathrm{mg} / \mathrm{L}$ at the
FM 1753 site); however, only two to four samples were collected at each tributary site during the study period.

Dissolved sulfate concentrations (table 3) also generally decreased in a downstream direction (fig. 3). The median dissolved sulfate concentration at the Red River near Terral site was $840 \mathrm{mg} / \mathrm{L}$ (table 3 ). The median concentration at the outflow site, Red River near Index, was $210 \mathrm{mg} / \mathrm{L}$. Median concentrations in the tributaries for small sets of samples (two to four) ranged from $48 \mathrm{mg} / \mathrm{L}$ (Bois D'Arc Creek at FM 100 near Honey Grove, Tex.) to $234 \mathrm{mg} / \mathrm{L}$ (Choctaw Creek at U.S. Hwy. 69 near Denison).

\section{Bacteria}

Bacteria densities in this reach (table 4) are a major concern for environmental managers because of the potential human health risk. Fecal coliform levels, determined from samples collected, resulted in segments of the reach being 
placed on the Clean Water Act 303(d) list of impaired or threatened waters (Texas Natural Resource Conservation Commission, 1997). Fecal coliform bacteria levels are an indicator of the degree of pollution and, therefore, the sanitary quality of a sample. The State standard for fecal coliforms is the geometric mean of 200 colonies per 100 milliliters (cols./100 mL) for several samples or 400 cols./100 mL for one sample (Texas Natural Resource Conservation Commission, 1997). Escherichia coliform densities also are used to assess the quality of recreational waters. Escherichia coliform is a natural inhabitant of the intestinal tract of only warm-blooded animals. The presence of Escherichia coliforms in water samples is an indication of fecal pollution and the possible presence of enteric pathogens (U.S. Environmental Protection Agency, 1996). Geometric mean densities of fecal coliforms did not exceed the TCEQ multisample standard at any of the sampling sites; however, the single-sample standard was exceeded at all sites except the Red River near Bonham site. The geometric mean density of Escherichia coliforms for five samples collected at the Red River near Terral site was 252 cols./100 $\mathrm{mL}$. Geometric mean densities for the remaining sites exceeded the TCEQ standard at Big Mineral Creek at FM 901 (270 cols./100 mL) and Choctaw Creek at U.S. Hwy. 69 near Denison (204 cols./100 mL).

\section{Dissolved Oxygen}

Adequate dissolved oxygen concentrations in surface water are necessary to sustain aquatic organisms and can indicate the general health of the water body. Dissolved oxygen concentrations can be depleted by processes that consume dissolved, suspended, or precipitated organic matter; and excess dissolved oxygen can be produced when biota are actively undergoing photosynthesis (Hem, 1985). The dissolved oxygen standard developed by TCEQ for the Red River is a 24-hour average concentration of $5.0 \mathrm{mg} / \mathrm{L}$ with an absolute minimum concentration of $3.0 \mathrm{mg} / \mathrm{L}$ (Texas Natural Resource Conservation Commission, 1997). Dissolved oxygen concentrations were measured continuously for 24 hours during July 1997 at two sites on the main stem, Red River at Arthur City and Red River near Index. Dissolved oxygen concentrations for Red River at Arthur City during July 30-31 ranged from 6.70 to $8.38 \mathrm{mg} / \mathrm{L}$. Dissolved oxygen concentrations for Red River near Index during July 28-29 ranged from 6.92 to $8.02 \mathrm{mg} / \mathrm{L}$. Dissolved oxygen concentrations generally are lowest during the hot summer months when the water temperature increases. These two data sets indicate that the dissolved oxygen standard was met.

- Stanley Baldys III ${ }^{1}$ and Danna K. Hamilton ${ }^{2}$

\section{References}

Baldys, Stanley, III, and Phillips, D.G., 1998, Stream monitoring and educational program in the Red River Basin, Texas, 1996-97: U.S. Geological Survey Fact Sheet 170-97, 6 p.

2000, Assessment of selected water-quality and biological data collected in the Wichita River Basin, Texas, 1996-97: U.S. Geological Survey Fact Sheet 110-00, 6 p.

Blazs, R.L., Walters, D.M., Coffey, T.E., Boyle, D.L., Kerestes, J.F., and Johnson, R.E., 1999, Water resources data, Oklahoma, water year 1998-Volume 2: U.S. Geological Survey Water-Data Report OK-98-2, 225 p.

Blazs, R.L., Walters, D.M., Coffey, T.E., Boyle, D.L., Kerestes, J.F., and White, D.K., 1998, Water resources data, Oklahoma, water year 1997-Volume 2: U.S. Geological Survey WaterData Report OK-97-2, 290 p.

Dallas Morning News, 2001, Texas Almanac, 2002-2003: Texas A\&M University Press, $672 \mathrm{p}$.

Gandara, S.C., Gibbons, W.J., Andrews, F.L., and Barbie, D.L., 1999, Water resources data, Texas, water year 1998-

\section{Information on technical reports and hydrologic data related to this study can be obtained from:}

District Chief

U.S. Geological Survey

8027 Exchange Dr.

Austin, TX 78754-4733

E-mail: dc_tx@usgs.gov
Volume 1: U.S. Geological Survey Water-Data Report TX-98-1, $530 \mathrm{p}$.

Gandara, S.C., Gibbons, W.J., Andrews, F.L., Jones, R.E., and Barbie, D.L., 1998, Water resources data, Texas, water year 1997-Volume 1: U.S. Geological Survey Water-Data Report TX-97-1, $532 \mathrm{p}$.

Hem, J.D., 1985, Study and interpretation of the chemical characteristics of natural water ( $3 \mathrm{~d}$ ed.): U.S. Geological Survey Water Supply Paper 2254, 263 p.

Keller, Jack, Rawson, Jack, Grubb, Hubert, Kramer, Jackson, and Sullivan, Glenn, 1988, Report on the evaluation of the effectiveness of operation of area VIII Red River Chloride Control Project: Red River Chloride Control Project Report, $35 \mathrm{p}$.

Texas Natural Resource Conservation Commission, 1997, Texas surface water quality standards: Texas Administrative Code, Title 30, Environmental Quality, part 1, chap. 307, 125 p.

U.S. Environmental Protection Agency, 1996, Drinking water regulations and health advisories: U.S. Environmental Protection Agency EPA-822-B-96-002, 16 p.

\footnotetext{
${ }^{1}$ U.S. Geological Survey.

${ }^{2}$ Red River Authority of Texas.
} 